\title{
PREPAREDNESS AND RESPONSE TO MIGRANT CRISIS AS AN INDICATOR OF "BALKAN ROUTE" STATES RESILIENCE
}

\author{
Zoran Keković, PhD \\ Faculty of Security Studies, University of Belgrade \\ E-mail: zorankekovic@yahoo.com \\ Marina Mitrevska, PhD \\ Faculty of Philosophy, Skopje \\ E-mail: marinamitrevska@yahoo.com \\ Jelena Dinić, PhD Student \\ Faculty of Security Studies, University Belgrade \\ E-mail:ydinic@yahoo.com
}

\begin{abstract}
Zenith of migrant crisis, arising as a result of the war in Syria and political turmoil in some Asian and African countries, took place in the year of 2015 testing the readiness and diplomatic relations of countries in the so-called "Balkan route" - the shortest transit corridor to migrants shelters in the EU. In terms of the migrant crisis, each country responded to the new circumstances in accordance with available capacities and interests. Preparedness and response to migrant crisis reflected the degree of Balkan states national security resilience, their ability to respond adequately to the changed circumstances in the security environment and to return to the normal state of functioning in the shortest time without compromising vital functions of the system. The sudden influx of migrants within a short period of time created the need for flexible and pragmatic responses of "Balkan route" states with the aim of prompt transit of migrants to final destinations in the EU. Subsequent unilateral actions of individual countries and the establishment of an agreement between Turkey and the EU
\end{abstract}


have led to the closure of "Balkan route" and generated progressive growth of migrants smuggling as well as using of alternative transit axes.

Key words: migrant crisis, "Balkan route", preparedness, response, resilience.

\section{Introduction}

Term "migration" has etymological roots in the Latin language (migration, migrare -wandering, roaming). United Nations defined migrations as the activity of "crossing state or administrative borders for a specific period of time by the refugees, internally displaced people and economic migrants" (UNESCO - Themes - Migration, 1998). Inability to achieve fundamental rights, graphically illustrated in the initial parts of the Maslow hierarchy (pyramid) of human needs (Maslow Lewis, 1987), represents primary motivator for migrations.

Activating of the so-called "Balkan route" - transit corridor from Greece through Macedonia, Serbia, Croatia and Slovenia which leads migrants to the desired destinations in the EU- was the result of a sudden influx of migrants in 2015 from civil war-torn Syria in 2015 and economic migrants who have left their home countries in Asia and Africa due to existential threats. The flow of a large number of people in a short period of time through aforementioned transit corridor generated political, humanitarian and security problems in Balkan countries who were instructed to cooperate, despite a constant influence of the burden of the past. Complex security situation in Balkan states during migrant crisis required implementation of pragmatic and flexible answers. Preparedness and response of each of these 'Balkan route' countries depended on the political and economic stability of individual countries as well as on the assistance in the form of information and material aid they received from other countries and organizations. 


\section{Securulianes}

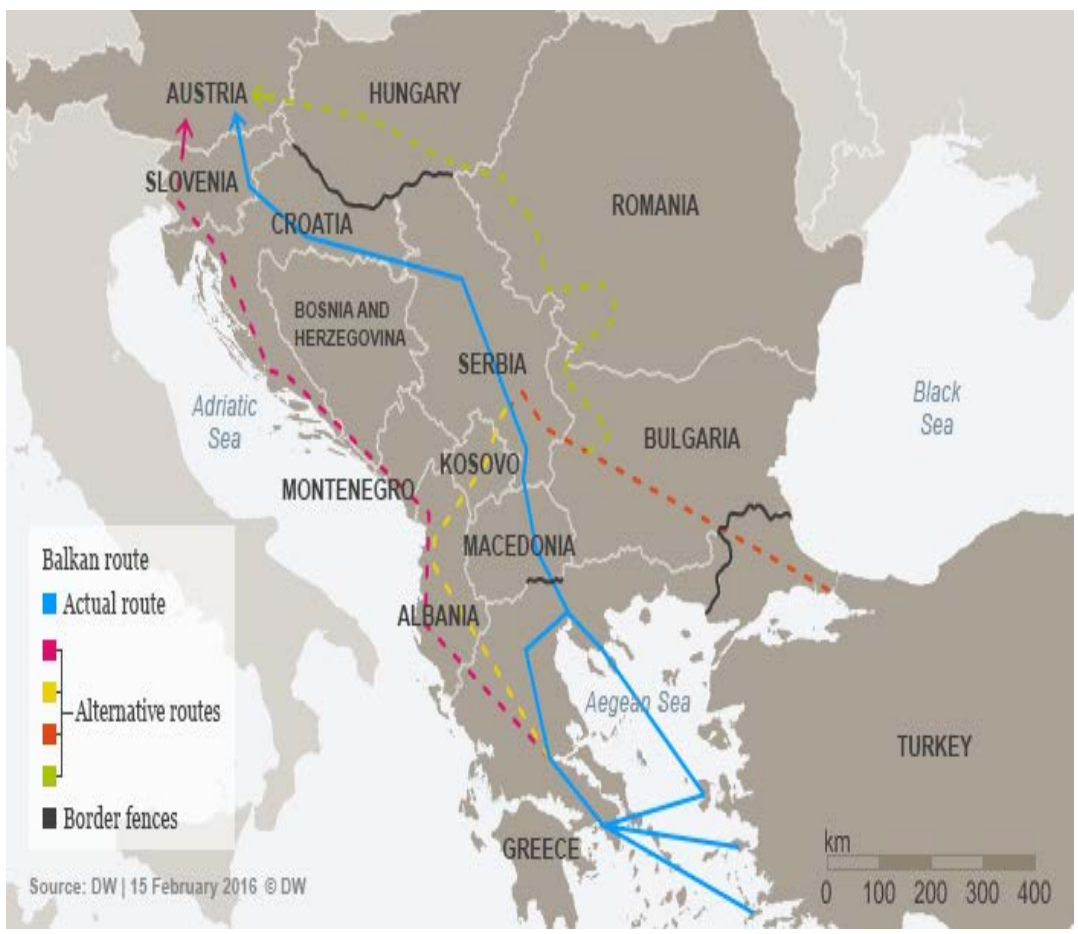

Figure 1:: "Balkan route" and alternative routes for transit of migrants (Deutsche Welle, 2015);

National security strategies of the Balkan states as "documents that define objectives of security policies, means and methods for the realization of national security interests and objectives" (Keković, 2009: 89) define migratory movements in various ways, placing them in the corpus of international and regional security risks and threats. The concept of resilience ${ }^{67}$ is implicitly mentioned in the security strategies of the Balkan states through the state's ability to apply preventive measures and strengthen national security system capable of a timely response, continuous functioning and maintaining vital functions and identities in the case of existing threats. Balkan countries that adapted functioning of the national security system to new circumstances and took advantage of them to improve the situation of national

\footnotetext{
${ }^{67}$ The term "resilience" is taken from the Technical Sciences whose researchers used it in the context of a resistance material which can withstand the external pressures and continue to perform its function and keep identity without permanent modifications of the structure (system).
} 
security can be characterized as countries that possessed characteristics of antifragility (Taleb, 2012).

State authorities and non-governmental organizations in several "Balkan route" countries reacted to the sudden influx of migrants in accordance with their capacities and interests. The data used in this paper were collected by analyzing publicly available documentation and through a questionnaire created for experts from the "Balkan Route" countries who were directly or indirectly engaged in the solving of migrant crisis. The authors of this paperwork presented indicators of resilience of transit countries for migrants on their way to final destinations in the EU:

- Institutional and organizational readiness of individual countries before the crisis outbreak in 2015;

- Reactions of state bodies and the high-ranking officials during the crisis;

- Changes in the legislation of the state affected by the crisis - the adoption of new laws, changes to existing normative acts;

-The involvement of security forces in dealing with the crisis -border police, the army and special units;

- Providing humanitarian and medical assistance at border checkpoints; transport of migrants;

- The reactions of citizens to migrants in transit;

- Reactions of the state structures to the pressures of EU officials;

- Institutional, informational and technical cooperation among "Balkan Route" countries;

- Recovery process of each country after "Balkan route" closure and response capacity improvement;

\section{Greece - "Balkan route" entry point}

During the year of 2015 and the first quarter of 2016 Greece, as the first country in the "Balkan route" corridor became the focus of public attention for several reasons. In the process of economic recovery from devastating effects of the global economic crisis, this EU country faced numerous problems due to the sudden influx of migrants and their transit to other Balkan countries. 


\section{Seccurity}

Institutional and organizational readiness of Greece to the sudden influx of migrants was not at the highest level due to the long process of recovery from the economic crisis as well as the lack of assistance from other countries and organizations in which Greece has had decades-long membership. The sudden influx of migrants who were trying to reach the eastern Greek islands from Turkish coast has led to the deaths of large numbers of people (UNHCR Report, 2015). Sharp reactions of Prime Minister Alexis Tsipras were results of the negligence of Turkish government and the unreadiness of Greek authorities (Coast Guard at first place) to the new situation due to a lack of logistical support from the EU (Squires, 2015). Bitterness of Greek authorities was the effect of lack of support from neighboring countries and EU institutions. This attitude dominated in all public appearances of high-ranked government officials during migrant crisis.

Political turmoil in the zenith of the migrant crisis led to dissolving of Greek parliament and the announcement of parliamentary elections in August 2015. The internal political dynamics and the election campaign conducted in the moments of the greatest humanitarian crisis since World War II has blocked legislative initiatives and amendments to normative acts with the aim of alleviating the effects of the migrant crisis. The law on the deportation of refugees and their return to the coast of Turkey was adopted in April 2016 as part of an agreement reached between top officials in Berlin and Ankara in March 2016 (European Commission, 2016).

Additional engagement of Greek police and special units on the eastern islands (such as Kos, Lesbos, etc.) was caused by increased demand for the establishment of public order after a large number of incidents provoked by the dissatisfied migrants due to the slow process of registration and distribution of meals (Konstatinidis, 2015). Humanitarian organizations significantly contributed to calming the situation (Papathanasiou, 2015) by providing assistance to migrants in the form of medical care and meals. Nongovernment organizations made transit of migrants through the territory of Greece bearable within the limits of fulfilling basic human needs on daily basis. Increased presence of security forces and thousands of migrants arriving daily in the Greek islands have led to dissatisfaction and solicitude of the local population for several reasons. Income from tourism as one of the strongest economic sectors of the country in the process of recovery from the economic crisis was decreased due to unwillingness of many tourists to spend their vacation in the islands which were geographically suitable for transfer of migrants from Turkey to Greek coast. Also, local 


\section{Seccurity}

residents were concerned about their own physical safety and health due to the potential risk of spreading diseases because of inadequate hygiene conditions in refugee camps (Haga, 2016).

During migrant crisis, senior Greek government officials met state officials of other "Balkan route" states and senior officials of EU at summits organized for adopting measures and plans for migrant crisis dismissal. Appeals of Greek authorities for humanitarian aid delivery to refugees who were coming in significant number on daily basis to the Greek island coast provided the sum of several hundred million $€$ of aid (European Parliament Briefing, 2015). Instead of stronger support and assistance from EU institutions, Greek authorities were faced with threats of suspension from Schengen zone because of the inadequate control of the external EU borders (BBC, 2015).

Incidents at the border crossings and the eastern Greek islands as well as the deficit of human and material resources were the reasons for the accusations directed to neighboring countries, especially to Turkey and Macedonia. Closure of "Balkan route" led to easing of tensions between Greece and its neighbors.

Migrant crisis recovery process in Greece has taken place simultaneously in terms of recovery from the economic crisis and the implementation of painful reforms of the tax and pension system, and therefore it is difficult to isolate indicators of migrants transit consequences in this country. Immediately after "Balkan route" closure, Greek authorities have directed attention to the recovery of tourism in the eastern Greek islands that were damaged due to migrant crisis (in the context of the recovery of local economy and undermined reputation) and to the implementation of the agreement between EU and Turkey that implies deportation of refugees to Turkish territory. Also, Greek authorities have made some improvements regarding accommodation conditions, acceleration of the examination of the international protection beneficiaries and applicants in the labour market (Skleparis, 2017). Surprisingly, tourism on eastern Greek islands bounced back after migrant crisis and brought more tourists to the islands in the years following the crisis (Morris, 2016).

\section{Preparedness and response of the Republic of Macedonia to the migrant crisis}

The creators of the Concept of national security and defense of the Republic of Macedonia pointed out that "the roots of instability in the region are in political 


\section{Seccurity}

extremism, extreme nationalism, religious and racial intolerance, which in combination with weak state institutions and the lack of rule of law can generate a high level of risk and danger" (The concept of national security and defense of the Republic of Macedonia, 2003). Migrations of population, especially illegal, are listed in the corps of security risks and dangers that come from the environment and can adversely affect national security of the Republic of Macedonia.

Migrant crisis befell the Republic of Macedonia in moments of political crisis and the escalation of inter-ethnic tensions. Fragile democratic institutions in this former Yugoslav republic were severely tested by a large flow of migrants during crisis. Absence of cooperation and coordination of government bodies in the period before the crisis had an impact on the level of readiness institutions of the sudden influx of migrants (Kosevaliska, Tusevski, 2015). Budget restrictions and insufficient quantity of humanitarian aid for migrants in transit were the root cause of Macedonian officials deprecation during 2015. In August 2015 Macedonian authorities declared emergency situation in and initiated an amendment to the Law on asylum (VOA, 2015) with the aim of facilitating migrants movement to the border with the Republic of Serbia and prevention of humanitarian crisis (the Guardian, 2015).

Initial phases of migrants transit through the Republic of Macedonia were significant in the light of additional engagement of border police and experts from the Crisis Management Center (Gallagher, 2016). Increasing number of transiting migrants during the summer of 2015 gave an impulse for decision made by the President of the Republic of Macedonia on the additional engagement of army forces at the border crossing points (Papadopoulou, 2015). Both numerous non-governmental organizations and citizens who organized themselves and provided support and care for migrants in transit by donating food and medical supplies got positive public reaction.

Perennial problems and tensions between Greece and Macedonia have influenced the level of cooperation and coordination between security services of mentioned countries during migrant crisis. Greece as a country multidecadal membership in NATO and the EU did not provide enough help to Macedonian security services (BBC, 2016). Cooperation with the authorities of the Republic of Serbia is assessed as positive and constructive by the Macedonian public, while relations with Brussels have been strained due to pressure from the EU regarding the structure of internal political turmoil and attitudes of governing structures (Herczog, 2016). During the crisis, Macedonian officials had several meetings with EU officials in Brussels. 


\section{Seccurity}

Valletta Summit gathered representatives of many European and African countries in order to discuss migrant crisis, but it was held without the presence of Macedonian officials (Valletta Summit on Migration 2015).

Closing of the "Balkan route" made Macedonian authorities faced with the problem of taking care of the refugees who are currently living on Macedonian territory.

"Second-in- chain" position within "Balkan route" corridor made Republic of Macedonia and its government an important partner in migrant crisis resolution, highlighting the role of the ruling elite's position. Cooperation of EU officials with "VMRO-DPMNE" representatives weakened the opposition and civil society, which led this country into deeper structural problems.

\section{Resilience of the Republic of Serbia in the context of the migrant crisis}

The Republic of Serbia as one of several countries on the transit corridor shared the burden with neighbouring countries regarding migrant crisis. The National Security Strategy of the Republic of Serbia recognizes migration as one out of numerous transnational challenges, risks and threats that may endanger national security (National security strategy of Republic Serbia, 2009).

In 2012 Serbian parliament adopted the Law on Migration (Law on Migration, 2012) which puts in charge Commissariat for Refugees and Migration to perform professional and other tasks related to the migration issues. This law emphasizes the role of Commissariat for Refugees and Migration to perform tasks related to: determining, proposing and taking measures for the integration of people who are, in accordance with the Law on Asylum (Asylum Act, 2007), entitled to asylum; identifying, proposing and taking measures for the reintegration of returnees under readmission agreements; improving the living conditions of IDPs while in displacement; proposing a program to develop a system of measures for families of foreigners who are illegally staying on the territory of the Republic of Serbia and proposing programs to support the voluntary return of foreigners who are illegally staying on the territory of the Republic of Serbia to their country of origin. Commissariat performs tasks related to: the collection, compilation and analysis of data and indicators for migration management; reporting on immigration and emigration; the development and regular updating of the migration profile of the Republic of Serbia; establishment of a unified 


\section{Secururity}

system for collecting, organizing and sharing data; establishing cooperation with the members of the European Migration Network; education and training of people engaged in activities relevant to migration management, ensuring the availability of information relevant to migration issues, as well as other duties specified by the Law. In June 2015 Serbian government established an Inter-ministerial working group for migrations under jurisdiction of Minister of labour, veterans and social rights. In July of the same year, Collection center for Refugees was opened in Presevo, as the first point for providing help to refugees in transit.

The Response Plan of the Serbian Government was adopted during the period of a sudden influx of migrants in September 2015 (Response Plan of the Government of RS to the sudden influx of migrants, 2015). As part of the Plan, certain activities and measures were adopted regarding institutions and organizations and their activities in the case of a massive transit of migrants. UNHCR and the International Organization for Migration (IOM) presented Annual plan of responses to refugee and migrant crisis in Serbia (Annual plan responses to refugee and migrant crisis in Serbia, UNHCR, 2015) in January 2017. The aforementioned plan is a part of the regional response which includes Serbia, Turkey, Greece and Macedonia.

In the early stages of the migrant crisis during the first half of 2015 the Covernment of the Republic of Serbia had an extensive experience towards migrants, following civilization and European norms and standards in terms of free movement of people, relying on the views of Germany's official policy, which advocated a liberal attitude and opening the borders to all migrants. The turnout has been created as a result of restrictive migration policy of neighboring countries, notably Hungary and Croatia, which increasingly began to pursue their national interests in terms of the migrant crisis, which led to the closure of their borders for the mobility of migrants (The Guardian, 2015). Increasing number of migrants in Serbia has resulted in the lack of sufficient resources for providing support to those people (Sputnik news, 2015).

Before the outbreak of the crisis, Serbia has had extensive experience with providing help to refugees and internally displaced people and in this context institutional and organizational readiness was at a high level. A significant contribution to mitigating the effects of the migrant crisis in the Republic of Serbia was made by a number of non-governmental organizations, the Red Cross, UNHCR and groups of citizens who have voluntarily donated aid in the form of food, clothing and medical material. During 2015, one of the first civilian organizations that organized help for 


\section{Seccurity}

refugees was "Miksalište" (Beta agency, 2015), providing assistance in the form of clothing, food, water and medical supplies at locations where gathering of a large number of migrants was recorded. During 2015, as a partner of the UNHCR, Info Center started to work in Belgrade, providing help with information as well as translator services (Ljubisavljević, 2015). Considering the transiting nature of migrants crisis, not a single incident was recorded between local population and refugees in Serbia (Spasojević, 2015).

Cooperation with neighboring countries has existed during the migrant crisis, but was not at the optimum level. Organized smuggling groups of migrants and closing of Hungarian border for transit of migrants have placed additional burden the Balkan states that had already been fighting with effects of migration crisis. Meetings of senior government officials with counterparts from neighboring countries took place mainly during the summit of leaders of the countries of the region with EU officials. Meetings of Balkan officials at the ministerial level were organized with the aim of calming tensions following the incidents and resolving situations that occurred in the context of the migrant crisis, threatening to endanger economic relations and the exchange of goods between countries (Beta, 2015).

The Ministry of Labor, employment, social and veterans' rights of the Covernment of the Republic of Serbia, in cooperation with the Commissariat for Refugees and Migration of the Republic of Serbia, UNHCR and NGOs, organized conferences and panels in order to gather eminent experts and discuss the experiences acquired at the field during the crisis, providing the impulse for starting institutional process of identifying lessons learned during the migrant crisis (Conference "Challenges of the refugee crisis -learned lessons" Conclusions and recommendations, 2016). Isolated incidents that happened in previous years in local communities (e.g. Banja Koviljaca "Asylum Protection Center" and in Subotica) were also a reason for civil society initiatives and recommendations directed towards government institutions (Migrants are not a threat but they are a security challenge for Subotica, 2017).

After the closure of the "Balkan route", joint patrols of Serbian army and police forces that were engaged to prevent illegal crossings of state border, thwarted smuggle attempts of more than 20000 migrants by 2017 (Press Release of Joint forces of the army and police of the Republic of Serbia, 2017). 


\section{The Republic of Croatia in terms of migrant crisis}

Creators of Croatian National security strategy recognized illegal migrations as one out of many asymmetrical security challenges, risks and threats (Croatian National security strategy, 2002). Migrant crisis in Croatia was marked by attempts of ruling structures to convince the public that the country is not the final destination of migrants and that a transit corridor for migrants transit from the Republic of Serbia will be directed towards Hungary. Also,as an integral part of Government's successful crisis communication strategy,the Croatian public was assured that in the case of migrant crisis outbreak, civil protection system which proved to be effective during the floods in Eastern Slavonia will be activated (Hina, 2014).

The Government of the Republic of Croatia made decision in July 2015 to establish Headquarters for Coordination of Activities with executive power in respect of all activities related to the receipt and transit migrants through the country. By the end of migrant crisis, Headquarters analyzed events and made strategic decisions and guidelines for all relevant actors activities. The most significant changes to the existing legislation were related to the amendments to the Law on State Border Control and the Law on Defense by which the Croatian Government has created a legal foundation for the Croatian armed forces to assist the border police. Although laws were amended, to the activation of the armed forces to assist the police never happened. Covernment's decision that has attracted great attention of the public was temporary employment of local unemployed population in the activities that were related to some form of assistance to migrants in the municipalities where they stayed during transit. In this way Covernment successfully used migrant crisis and temporarily decreased unemployment in local communities.

All activities of state and a non-state sector, domestic and international civil organizations in humanitarian embodiment have been coordinated and synchronized with each other. Headquarters for coordination of activities was established by the Government and it was making strategic guidelines for activities in the migrant crisis, while the operational headquarters made up of all government forces involved in the intervention, was deciding upon operational activities of all the forces engaged.

Reactions of Croatian citizens at the beginning of the migrant crisis were divided, with emphasis on the increasing the number of citizens who supported assistance to migrants. During the migrant crisis, there have been no security incidents 


\section{Seccurity}

during the transport of migrants or in transit camps. The Republic of Croatia did not allow migrants to move freely through the national territory, they have been accepted at the border, registered, provided with medical, psychological and other humanitarian aid and transported to the border with Slovenia.

Croatian police exchanged information with neighboring countries on daily bases. The blockade of Bajakovo border crossing point due to non-compliant policy of the Republic of Serbia regarding transport of migrants to certain border points was terminated without lasting consequences for relations between the two countries (Beta, 2015). The strategic decision of the Croatian Government to ban the free movement and retention of migrants has had a key role in the protection of national security during the migrant crisis. Efficient civil protection system gave additional contribution in dealing with the migrant crisis (Information on the state system of civil protection, 2015).

\section{Preparedness and response of the Republic of Slovenia to the migrant} crisis

Economic and political stability of Republic of Slovenia was confirmed by gaining membership status in the EU and NATO. Relatively high institutional and organizational readiness for migratory wave is the result of longstanding process of building democratic institutions, rule of law and the harmonization of the national security system with EU and NATO.

The strategy of national security of the Republic of Slovenia (Resolution on the National Security Strategy of the Republic of Slovenia, 2010) identified illegal migration as a form of threat to the national security in the context of global sources of threats and risks. The creators of the Strategy claim that "the pressure of migrating from the direction of Southeast Europe is conditioned by socio-economic factors and the security situation at the above mentioned as well as on a global basis. Mass migration in the future may generate security threats and threaten the health of the nation "(Resolution on the National Security Strategy of the Republic of Slovenia, 2010).In this way, Slovenian policymakers made a relation between illegal migrations and potential health crises. 


\section{Seccurity}

After closing of the Hungarian border, the Republic of Slovenia has been faced with a massive influx of migrants who use the territory of the country as a transit corridor to Austria and Germany (Pusterla, 2015). Slovenian lawmakers did not foresee the involvement of the army in the field of civil protection during emergencies which caused an overload and the deficit in the number of police officers deployed during the initial phases of migrant crisis.After the meeting of the National Security Council in October 2015, a decision was made on hiring Armed forces in assisting the police forces was made (BBC, 2015).

The UNHCR and the Red Cross were permanently present at border crossings and checkpoints, helping the authorities to register people with special needs and provide them with additional humanitarian aid. Assists that listed organizations and individual citizens provided to migrants in transit were not sufficiently covered in the media because of a negative attitude of the public towards immigrants who were considered to be a threat to national security (Green Journal, 2017).

Good organization of the security services and non-governmental sectors in the management of migrants in transit caused the absence of significant pressures from EU institutions. European Commission donated dozens of millions of euros for the construction of additional accommodation and as an aid for security services (UNHCR Europe's refugee emergency response update \# 10, November 2015). Cooperation of the Republic of Slovenia with neighboring countries was solid except for bilateral tensions with the Republic of Croatia on the occasion of transit of 25000 migrants in a period of a few days in October 2015 (SLOGA, 2015). That situation forced officials of Croatia and Slovenia to seek the help of police forces of other EU member states.

A few months after critical attitude towards the construction of the wall in the Hungarian-Serbian border, the Government of the Republic of Slovenia has applied identical measures to protect the Schengen area and to prevent the creation of "stoppage" in the movement of migrants to Austria. The Republic of Slovenia, a politically stable and geographically smallest state of "Balkan route", did not have major consequences due to migrant crisis, unlike Greece which, after signing of the "EUAnkara" contract was faced with the disposal of tens of thousands of migrants detained on the border with the Republic of Macedonia. 


\section{Conclusion}

Resilience of individual Balkan countries in the context of the migrant crisis in 2015 is a complex phenomenon made up of a large number of factors that in different ways contributed to their preparedness and response to migratory wave. Migrant crisis tested the institutional and organizational readiness of individual countries of "Balkan route" and their fragile bilateral relations burdened with the past.

Because of the dealing with the consequences of the global economic crisis and its position as the first country in the Schengen area for migrants, the Hellenic Republic has brought an exceptionally heavy burden during the migrant crisis. Unsatisfactory level of cooperation with Turkish and Macedonian authorities has further aggravated the efforts of the Greek authorities to register migrants and transport them to the exit border checkpoints. Closing of "Balkan route" corridor has created a problem with the disposal of tens of thousands of migrants who remained "trapped" on the GreekMacedonian border. The Republic Macedonia and the Republic of Serbia, despite a satisfactory level of security services cooperation and help provided by international and non-governmental organizations, faced a lack of resources to care for a large number of migrants who spent a transit period in those countries. The Republic of Croatia and the Republic of Slovenia showed a high degree of organization and preparedness migrants during the crisis, according to the collected data. Despite sporadic misunderstanding due to non-compliance at the bilateral level, those countries managed prompt reactions involving competent services to provide necessary humanitarian assistance and efficient transportation of migrants to the end "Balkan route".

"Balkan route" was officially closed by signing the "EU-Ankara" contract in March 2016. That agreement led to the weakening of previous migratory pressures towards Balkan countries, creating potential for organized crime activities in the form of smuggling migrants through alternative transit corridors.

\section{Literature:}

1. Maslow, A., Lewis, K.J., (1987) Maslow's hierarchy of needs. Salenger Incorporated 


\section{Securiagues}

2. Keković, Z. 2009. "0 nacrtu Strategije nacionalne bezbednosti Republike Srbje“, časopis Vojno delo, 2/2009, str.89

3. Miller, D.S. and Chtouris, S., (2017) Borderland Security and Migration: Balancing Humanitarian Response with Crisis Preparedness \& Emergency Management- The Social and Cultural Challenges to Homeland Security. Journal of Applied Security Research, 12(1)

4. Kosevaliska, 0., Tusevska, B. and Nikodinovska Krstevska, A., (2015) Migration crisis: Macedonia on crossroads.

5. Kozarev, A., (2008) Bezbednosni sistem u Republici Makedoniji-izazove i perspektive. Journal of Criminal Justice Issues (Kriminalisticke teme), 7.

6. Koncept nacionalne bezbednosti i odbrane Republike Makedonije (2003)

1. KEKENOVSKI, J., (2016) REPUBLIC OF MACEDONIA AND REFUGEE CRISISbetween the hammer and the anvil. Horisons series $A, 19$.

2. Zakon o upravljanju migracijama "SI. glasnik RS", br. 107/2012

3. Zakon o azilu "Službeni glasnik RS", broj 109/07

4. Zupančič, J., (2016) The European refugee and migrant crisis and Slovenian response, EJG, 4

5. Pusterla, F. and Pusterla, E., (2015) The 2015 migrant crisis and EU Member States: the relation between state fragility and solidarity. European Political Science,

6. RE S O L U T I O N on the National Security Strategy of the Republic of Slovenia, OFFICIAL GAZETTE OF THE REPUBLIC OF SLOVENIA No. 27/2010, dated 2 April 2010

7. Taleb, N. (2012). Antifragile: Things that Gain from Disorder. New York: Random House, 301-335.

8. Web sources:

9. "Migrant crisis: Nato deploys Aegean people-smuggling patrols", BBC News

10. http://www.bbc.com/news/world-europe-35549478(12.mart 2017.)

11. Squires, N. (2015) "Migrant crisis makes me ashamed to be in EU, says Greek PM" The Telegraph

12. http://www.telegraph.co.uk/news/worldnews/europe/greece/11966747/Migran t-crisis-makes-me-ashamed-to-be-in-EU-says-Greek-PM.html(19.mart 2017.)

13. Clayton, J. (2015)"Million sea arrivals reach Europe" 
14. http://www.unhcr.org/afr/news/latest/2015/12/5683d0b56/million-seaarrivals-reach-europe-2015.html(21.mart 2017.)

15. Konstatidinis, A. (2015) "Greece sends cruise liner, extra police to help island of Kos with migrant crisis"

16. http://www.reuters.com/article/us-europe-migrants-greeceidUSKCNOQH1YY20150812(21.mart 2017.)

17. European Commission Press Release Database

18. http://europa.eu/rapid/press-release_MEM0-16-963_en.htm(20. mart 2017.)

19. Papathanoslou, K. (2015) "Stop Migrant Suffering in Creece; List of Top Humanitarian Organizations"

20. http://greece.greekreporter.com/2015/09/04/stop-migrant-suffering-ingreece-list-of-top-humanitarian-organizations/(21.mart 2017.)

21. "Migrant crisis: Greece denies Schengen threat from EU" BBC News

22. http://www.bbc.com/news/world-europe-34983426(25.mart 2017.)

23. Haga, C. (2016) "Extra medics drafted in as risk of epidemics rises in Greece"

24. http://www.ifrc.org/es/noticias/noticias/europe/greece/extra-medics-draftedin-as-risk-of-epidemics-rises-in-greece-72066/ (21.mart 2017.)

25. European Parliament Briefing - the Western Balkans frontline of the migrant crisis

26. http://www.europarl.europa.eu/RegData/etudes/BRIE/2016/573949/EPRS_BR I(2016)573949_EN.pdf(26. mart 2017.)

27. European Commission press release

28. http://europa.eu/rapid/press-release_IP-16-1447_en.htm(26. mart 2017.)

29. Slovenia, Serbia and Croatia move to close migrant route, Deutsche Welle

30. http://www.dw.com/en/slovenia-serbia-and-croatia-move-to-close-migrantroute/a-19102872( 21. mart 2017.)

31. UNESCO - Themes - Migration

32. http://www.unesco.org/new/en/social-and-humansciences/themes/international-migration/glossary/migrant/(12. april 2017.)

33. "Macedonia declares state of emergency to tackle migrant crisis" The Guardian

34. https://www.theguardian.com/world/2015/aug/20/macedonia-state-ofemergency-migrant-crisis(16.april 2017.)

35. "Macedonia Allows Migrants to Legitimately Transit Country", VOA News 
36. http://www.voanews.com/a/macedonia-migrants-asylumlaw/2828577.html(16.april 2017.)

37. Gallagher, L.(2016.)SPECIAL UMD REPORT: Macedonia's Involvement in the Migrant Crisis

38. http://apo.org.au/files/Resource/umd-report-macedonia-s-involvement-inthe-migrant-crisis.pdf(16.april 2017)

39. "Macedonian army allows migrants to cross border" The Guardian

40. https://www.theguardian.com/world/2015/aug/23/macedonian-army-allowsmigrants-to-cross-border(16. april 2017.)

41. How is the migrant crisis dividing EU countries? BBC News

42. http://www.bbc.com/news/world-europe-34278886(16. April 2017.)

43. Herczog, E. (2016) "Europe can't afford to be blackmailed by Macedonia"

44. http://www.politico.eu/article/europe-blackmailed-macedonia-refugee-crisisbalkan-route-greece/ (16. april 2017.)

45. Valletta Summit on Migration 2015

46. http://www.consilium.europa.eu/en/meetings/internationalsummit/2015/11/11-12/(17. april 2017.)

47. "Macedonia Is Still Waiting on EU Financial Aid Intended for Dealing with Migrant Crisis"

48. http://www.independent.mk/articles/23523/Macedonia+ls+Still+Waiting+on+ EU+Financial+Aid+Intended+for+Dealing +with+Migrant+Crisis(17. April 2017.)

49. Strategija nacionalne bezbednosti Republiuke Srbije, oktobar 2009.

50. http://www.mod.gov.rs/multimedia/file/staticki_sadrzaj/dokumenta/strategije /Strategija\%20nacionalne\%20bezbednosti\%20Republike\%20Srbije.pdf

51. "Hungary closes border to refugees as Turkey questions EU deal to stem crisis" France Presse

52. https://www.theguardian.com/world/2015/oct/17/hungary-closes-border-torefugees-as-turkey-questions-eu-deal-to-stem-crisis(17. april 2017.)

53. "Serbia Not Receiving Enough EU Help to Tackle Refugee Crisis" Sputnik News

54. https://sputniknews.com/europe/201510301029360036-serbia-eu-helprefugee-crisis/ (17. april 2017.)

55. Plan reagovanja Vlade RS na nagli priliv migranata

56. http://www.minrzs.gov.rs/files/doc/migranti/Plan\%20Vlade0001.pdf

57. Godišnji plan reagovanja na izbegličku i migrantsku krizu u Srbiji 
58. http://www.unhcr.rs/media/docs/2017/januar/RMRPSerbiaSRP.pdf (17.april 2017)

59. "Srbija i Hrvatska: da li će biti trgovinskog rata?" Agencija Beta

60. http://www.euractiv.rs/srbija-i-eu/9164-srbija-i-hrvatska-da-li-e-bititrgovinskog-rata

61. (17.april 2017)

62. Konferencija "Izazovi izbegličke krize -naučene lekcije" Zaključci i preporuke

63. http://www.sos-decijasela.rs/wp-content/uploads/2016/06/Izve\%C5\%A1tajsa-konferencije-Izazovi-izbegli\%C4\%8Dke-krize-Zaklju\%C4\%8Dci-i-preporukeSOS-DS.pdf(17.april 2017)

64. Press Release of Joint forces of the army and police of the Republic of Serbia

65. http://www.mod.gov.rs/lat/10092/saopstenja-komande-zajednickih-snagavojske-i-policije-10092(18.april 2017)

66. "Pomoć UNHCR-a Vladi Srbije za izbeglice dostigla million evra"

67. http://www.unhcr.rs/dokumenti/saopstenja-za-medije/pomoc-unhcr-a-vladisrbije-za-izbeglice-dostigla-milion-evra.html(18.april 2017)

68. Informacija o stanju sustava civilne zaštite

69. http://www.obz.hr/hr/pdf/2016/19_sjednica/15_informacija_0_stanju_sustava _civilne_zastite.pdf(19.april 2017)

70. "Migrant crisis: Slovenia army to help police", BBC News

71. http://www.bbc.com/news/world-europe-34559419(21.april 2017)

72. "Genesis of Fear: The Case of Slovenia" Green Europe Journal

73. http://www.greeneuropeanjournal.eu/genesis-of-fear-the-case-ofslovenia/21.april 2017

74. "SVIMA PRUŽILI POMOĆ: Za godinu dana kroz Miksalište prošlo 150.000 migranata" Agencija Beta

75. http://www.vesti.rs/Sport/SVIMA-PRUZILI-POMOC-Za-godinu-dana-krozMiksaliste-proslo-150-000-migranata.html(28.april 2017.)

76. Ljubisavljević, S. (2015)0tvoren Info-centar za azil u Beogradu

77. http://www.rts.rs/page/stories/sr/story/125/drustvo/2015717/otvoren-infocentar-za-azil-u- beogradu.html(28.april 2017.)

78. Spasojević, C. (2015) "Srbija ubrzava, Brisel želi da uspori izbeglice"

79. http://www.novosti.rs/vesti/naslovna/drustvo/aktuelno.290.html:562534Srbija-ubrzava-Brisel-zeli-da-uspori-izbeglice(28.april 2017.) 
80. Skleparis, D. (2017) The Greek response to the migration challenge: 2015-2017 http://www.kas.de/wf/doc/kas_48205-1522-1-30.pdf?170327142603 (05. May 2017)

81. Morris, H. (2016)Greece expects a bumper year for tourism despite 'unfair' coverage of migrant crisis

82. http://www.telegraph.co.uk/travel/destinations/europe/greece/articles/greekislands-unaffected-by-migrant-crisis-and-ready-for-next-su/(05. May 2017)

83. Migrants are not a threat but they are a security challenge for Suboticahttps://www.subotica.info/2017/03/21/migranti-nisu-pretnja-ali-jesubezbednosni-izazov-za-suboticu(05. May 2017)

84. Croatian National security strategy(2002)

85. https://www.soa.hr/UserFiles/File/Strategija_nacionalne_sigurnosti_RH.pdf(05 . May 2017) 